A N N A L E S

UNIVERSITATIS MARIAE CURIE-SKŁODOWSKA

LUBLIN - POLONIA

VOL. LXV, 1

SECTIO G

2018

Maria Curie-Skłodowska University, Lublin

Provincial Administrative Court, Lublin

aostrowska7@gazeta.pl

ANNA OSTROWSKA

\title{
Administrative and Legal Conditions for the Development of Wind Power Generation Industry in Poland
}

Administracyjnoprawne uwarunkowania rozwoju energetyki wiatrowej w Polsce

\section{INTRODUCTION}

On July 15, 2016, a legal act entered into force, which electrified the business community, especially the unconventional energy industry, local government authorities, and all those who saw the development of the alternative energy sector as the only solution for the global energy crisis. This is about the Act of 20 May 2016 on Investments in Wind Power Plants, ${ }^{1}$ which set out the conditions, rules and procedures for the location and operation of wind farms with a power greater than the power of a micro installation (Art. $2 \S 1$ in conjunction with Art. $2 \S 19$ of the Act of 20 February 2015 on Renewable Energy Sources²), as well as the conditions for the location of housing developments (residential buildings and mixed-use buildings) in the vicinity of wind farms. ${ }^{3}$

This Act has been named, both by scholars of law and the media, "another special legislation", although it is not a typical special legislation. Although it is a lex

1 Journal of Laws, item 961, hereinafter referred to as u.i.e.w.

2 Journal of Laws of 2016, item 925.

3 Pursuant to Article $1 \S 2$ of the Act, its norms shall not apply to wind power plants with a power greater than the power of micro installations implemented and used in the maritime areas of the Republic of Poland within the meaning of the Act of 21 March 1991 on maritime areas of the Republic of Poland and maritime administration (consolidated text Journal of Laws of 2013, item 934, as amended). 
specialis in relation to the Act of 7 July 1994 - Construction Law, ${ }^{4}$ as well as the Act of 27 March 2003 on Spatial Planning and Land Development, ${ }^{5}$ its provisions, unlike any "special legislation", do not introduce preferential conditions for investors with regard to identifying location and authorization for the project covered by it. On the contrary, they introduce a number of significant constraints in the process. This Act does not establish rules that would be separate from the standard regulation of the investment and construction process, and it does not interfere with the model of judicial control of administrative decisions and does not limit the jurisdiction of the administrative courts. Unlike the preceding legislation, it does not establish one integrated procedure combining several separate stages of investment preparation, completed with the issuance of an integrated individual administrative act specifying the conditions for the preparation and implementation of an infrastructural project (project implementation permit). It also does not offer an alternative to the above solution, namely it does not provide for the separation of the two basic stages of the procedure: the first, covering the planning and partitioning process, completed with the localization decision, exerting an expropriation effect by virtue of law, and the second, finished with the decision on the building permit and approval of the building permit design, since it introduces the principle of wind farm construction solely on the basis of local spatial development plans.

The adoption of the Act of 20 May 2016 was driven by the fast pace of development of wind energy generation industry in Poland. By 15 July 2016, there were no provisions governing the location, construction and operation of wind farms, that involved the specificity of these structures, and consequently many of such power plants have operated too close to residential buildings. This has caused numerous conflicts between local authorities and inhabitants of the municipalities. The latter are concerned that these devices emit noises, inaudible infrasounds, vibrations, light flickering, and may also pose a direct threat to human life or health in case of failure or wind turbine blade icing during winter.

The Act has retained the principle that obtaining a building permit is needed before the construction of a wind farm, and where the project is classified as a project of significant environmental impacts a separate procedure for environmental decision is also required to be conducted. The most significant modification of the general principles governing the investment and construction process is that a wind farm construction is only permitted under a local spatial development plan, which means that the option of decision on land development conditions for such a project was waived. Another one is the introduction of very restrictive distance standards for the mutual location of wind farms and residential buildings or buildings intended for the stay of people.

4 Consolidated text Journal of Laws of 2016, item 290, as amended.

5 Consolidated text Journal of Laws of 2016, item 778, as amended, hereinafter: u.p.z.p. 


\section{DILEMMAS RELATED TO THE LOCATION AND CONSTRUCTION OF WIND POWER PLANTS BEFORE THE ENTRY INTO FORCE OF THE ACT ON WIND POWER PLANT PROJECTS}

Prior to the date of entry into force of the Act on Investments in Wind Power Plants, there was a problem related to the location of this type of power plant under a decision on land development conditions and land use. In the Polish spatial planning and land use system there are two types of decisions on land development and land use; the first one is the decision to establish the location of a public-purpose project, the second one is the decision on development conditions being issued for projects that are not public purpose projects. Obtaining the first of them is much simpler for the investor, for example, due to the fact that the decision to establish the location of a public-purpose project is issued by the authority when the planned project does not infringe separate regulations. On the other hand, the case is different for the decision on land development conditions, for which the prerequisites set forth in Art. $61 \S 1$ of the Planning and Land Development Act must be met.

Beyond any doubt, a construction project in the form of a wind farm is not a public investment. It was not listed in the catalogue of projects of this kind in Art. 6 of the Act of 21 August 1997 on Real Estate Management. ${ }^{6}$ Therefore, before the Act on investments in Wind Power Plants became effective, in the absence of a local development plan, the investor had to obtain a decision setting out the conditions for the development of the wind power plant. And here another problem has arisen, which comes down to the question: does the decision on development conditions require to comply with the condition of the so-called good neighbourhood specified in Art. 61.1 point 1 u.p.z.p., ${ }^{7}$ which would not, as a rule, be feasible for this type of project, and also the condition of access to a public road, mentioned in point 2 of that provision.

6 Consolidated text Journal of Laws of 2015, item 1774, as amended, hereinafter: u.g.n. A wind farm cannot be classified as pipes/cables and equipment used for transmitting or distributing gases and electricity, as well as other facilities and equipment necessary for the use of these pipes/cables and equipment (Art. 6 § 2). In the judgement of 10 June 2010, II SA/Bk 288/10, LEX No. 737343, the Regional Administrative Court in Białystok pointed out that at present only the construction and maintenance of cables and devices strictly used for the transmission of electricity was ex definitione a public purpose. To have the status of a public-purpose project, it is not enough to draw a functional link between a power generating device and transmission devices or a power transmission system, such link is relatively easy to obtain in a system of power facilities and equipment. Art. 6 u.g.n. contains a closed list of public purposes. Power plant does not constitute a public-purpose project.

7 It is about the requirement that at least one neighbouring plot of land, accessible from the same public road, should be developed in a way allowing defining requirements for new developments in terms of continuity of functions, parameters, characteristics and indicators of building and land development, including size and architectural form of buildings, building line and intensity of land use (Art. $61 \S 1$ point 1 u.p.z.p.). 
Despite the initial divergences between the scholarly opinion and jurisprudence in this respect, it has been assumed, however, that a wind farm should be classified as a technical infrastructure within the meaning of Art. $143 \S 2$ u.g.n. It was important because in the case of projects involving the location of technical infrastructure equipment, the issuance of a decision to establish the conditions of development does not require the fulfilment of the condition of the so-called good neighbourhood or the condition of access to the public road (Art. $61 \S 3$ u.p.z.p.).

In practice, this meant the possibility of building wind farms in very close proximity to even densely populated areas, causing inconvenience to their inhabitants and chaos in urban planning. This has become a direct impulse to eliminate from the sphere of wind power generation a legal instrument in the form of location decision.

But that is not all, because before the Act became effective there had been numerous scholarly and jurisprudential disputes, in wind farm building permit proceedings, about the determination who - apart from the investor - has the right to stand as a party to the proceedings. Each time it was emphasized that a

wind power plant is an unusual undertaking, for example, because its effect on space is not fully known. In addition, the impact of facilities of this type depends on the type of device, its power, tower height, rotor size, profile of the area and many other factors. What is more, the courts considered that it was also important to establish who was a party to the proceedings, and whether there were residential, industrial or agricultural or forestry grounds located near the wind farm. ${ }^{8}$

In view of the above, the above-mentioned circumstances should be taken into account when identifying entities acting as parties to the proceedings in the present case. The fact that the person concerned does not own the plot located directly near the plot on which the wind farm is to be located cannot be decisive in finding about the lack of legal interest in these proceedings.

Prior to the entry into force of the Act of 20 May 2016, there were no standards defining the distances of wind power plants from the borders of neighbouring properties, including those intended for residential purposes. Due to the characteristics of wind power plants, noise emitted by wind turbines was the essential factor in establishing the area of effect of such facilities on adjacent areas. According to $\S 1$ of the Regulation of the Minister of Environment of 14 June 2007 on Permissible Noise Levels in the Environment, ${ }^{9}$ the acoustic protection covered, inter alia, areas intended for single-family and multi-family housing, residential and service housing and farm buildings, hospitals and social care homes, as well as for buildings related to permanent or temporary residence

8 Cf., instead of many judgements: Judgement of the Supreme Administrative Court of 16 May 2014, II OSK 2980/12, LEX No. 1586384.

9 Consolidated text Journal of Laws of 2014, item 112, as amended. 
of children and adolescents. No agricultural land is covered by noise protection. For plots for farming purposes and the development of which is forbidden, no noise level standards shall apply.

\section{DOES THE END JUSTIFY THE MEANS?}

One of the most important modifications made by the Act of 20 May 2016 is that the location of a wind power plant is exclusively based on a local land use plan. This solution - as its supporters point out - eliminates the risk related to locating wind farms under an administrative decision, issued for a single investor, which does not require taking into account the character and function of the environment of such an investment.

It is true that the planning procedure, however long and costly, has the undoubted advantage of being transparent and open. Any stakeholder may take part in it by submitting proposals to the plan, participating in public discussion of the solutions provided for in the plan and commenting on the draft plan. The requirement to adopt a local land use plan creates the prospect that locating wind power plants will be the result of a long-term spatial policy of the municipality, rather than the result of ad-hoc, individual decisions, ignoring the long-term perspective of spatial and social development of the municipality. This solution also facilitates the valuation of the property and any possible claims related to the limitation of land use, i.e. the possibility of locating housing on it, and significantly simplifies the procedure for acquiring a wind farm building permit and any building projects located in the areas covered by the local land use plan (excluding housing development) - because the investment process will be limited only to the construction and implementation stage. The simplification concerns the investor and public authorities - to investigate the correctness of the location and to maintain the minimum distance prescribed by the law, the local plan extract and map extract will suffice. ${ }^{10}$

The local plan shall be drawn up at least for the area in which, pursuant to Art. $4 \S 1$ of the Act, no new housing or mixed-use buildings may be located, which includes a residential function, and whose boundaries are determined taking into account the maximum total wind power specified in that plan. This regulation is intended to prevent one municipality from taking a decision that would negatively affect the development and activities of other municipalities. It will no longer be possible to locate wind farms near the municipality boundaries so that a significant portion of the negative impact of the power plant is on the area of other municipalities, as has often been the case when wind farms were

${ }^{10}$ From the grounds for the draft Act of 20 May 2016, http://www.sejm.gov.pl/sejm8.nsf/druk. xsp?nr=315 [access: 01.06.2017]. 
located on the basis of a land development decision. The municipal authorities may only approve a local plan only within the limits of their jurisdiction, subject to the prescribed distance. This means, however, that small-area municipalities will have no possibility of locating wind farms, in view of the current distance requirements.

Also the individual regulations of the Act regarding local plans contain significant flaws. According to Art. $7 \S 2$, in the explanatory memorandum attached to the draft resolution on commencing to draw up the local plan (the so-called resolution of intent) providing for the location of a wind farm shall in particular include the maximum total height of the wind farm that will be specified in that plan. Such a solution contradicts the purpose of a resolution of intent, which is the first formalized stage of the planning process that takes place before the draft plan is drawn up.

The resolution of intent expresses the intention of the municipality to regulate the issue of intended purpose and the way of development and use of a given area (usually a certain fragment of the municipality area) by way of an act of universally applicable law, namely a local plan. The content of the resolution on commencing to draw up the local plan contains the communication of the initiation of the appropriate planning process and the descriptive and graphical designation of the boundaries of the area to be governed by the future local plan. ${ }^{11}$ The resolution of intent cannot anticipate the content of the resolution on the plan itself (Art. $20 \S 1$ in conjunction with Art. $15 \S 2$ and 3 u.p.z.p.). It is not allowed, at the stage of drawing up a plan, to set the rules of land development, since such competence is not acquired by the municipal council until the plan is adopted. By introducing the requirement to specify in the grounds for the resolution (even not in the resolution itself) the maximum total height of the wind farm, the legislature has acted against this rule. Such a determination should only be made in the draft plan prepared by the mayor, and then in the plan adopted.

Another novelty is the precise definition of the distances in which the following items may be localized and built: 1) wind power plant - from a residential or mixed-use building with residential function, and 2) a residential or mixed-use building with residential function - from a wind power plant; 3) wind power plant from the forms of nature protection referred to in Art. $6 \S 1$, points 1-3 and 5 of the Act of 16 April 2004 on Nature Conservation and Promotional Forest Complexes referred to in Art. $13 \mathrm{~b} \S 1$ of the Act of 28 September 1991 on Forests. This distance in each of the above cases is equal to or greater than ten times the

11 Judgement of the Supreme Administrative Court of 13 September 2005, II OSK 64/05, LEX No. 194989; Judgement of the Regional Administrative Court of 25 September 2008, II SA/ Bk 441/08, LEX No. 475214; Judgement of the Regional Administrative Court in Łódź of 28 May 2007, II SA/Łd 1046/07, LEX No. 486528. 
height of the wind farm measured from the ground level to the highest point of the structure, including technical elements, in particular rotor with blades (total height of the wind power plant).

The proponent of this solution has pointed out that this is a size that provides "physical" safety - because ten times the height of the centre of the rotor is the distance at which the elements thrown away by rotor blades (e.g. frozen snow, ice) and the fragments of the blade would fall down, according to physical calculations. However, given the fact that it is possible (e.g. during strong winds) that elements thrown away by the blades be moved at greater distances, and the fact that the impact of the wind turbine on its surroundings results from its total height, the total height of the wind power plant has been proposed as the basis for determining the minimum distance. Data on nuisance generated by wind power plants were also analysed for distance determination, which allowed defining the need to protect human residential areas against: 1) noise and infrasounds; 2) electromagnetic radiation; 3) vibration; 4) flickering of shadow and light reflections. When adopting this distance, the proponent also took into account the visual impact.

At this point, however, the legislature's intentions and declarations must be confronted with problems that may occur (and will inevitably occur) in practice.

First of all, it should be assumed that the average height of a wind turbine with a rotor is $150 \mathrm{~m}$ (there are also wind farms in Poland having a total height of over $200 \mathrm{~m}$ ). The necessity of maintaining the distance between the wind farm and residential buildings $(10 \times$ total height of a wind turbine) specified in the law means that within a radius of $1.5-2 \mathrm{~km}$ from the power plant there is an area in which it is prohibited to locate any buildings with a residential function. In fact, however, this distance will be even greater due to the manner of its delineation set out in Art. 5 . Where a residential building or building with residential function is located on the plot (or there is a valid building permit decision issued or effective notification of such a building is made), the distance shall be determined as the shortest distance between the vertical projection of the building and the circle whose radius is equal to half of the diameter of a rotor with blades, and the centre is the centre of the circle circumscribed on the outline of the tower of an existing wind power plant, or the line delimiting the area whose manner of use defined in the local plan permits the construction of a wind farm. On the other hand, if there is no residential building or building with residential function on the plot, this section starts at the boundary of the area covered by the decision on the conditions of development, providing for the location of such a building. Where a local plan is in place for the area, the beginning of the section is the line delimiting the area whose manner of use defined in the local plan permits the construction of such a building (Art. $5 \S 1$ and 2 u.i.e.w.).

It is very clear that when this distance is calculated from the boundary of the area covered by the decision on the conditions of development or the line delimiting the area whose manner of use defined in the local plan permits the construction 
of a building with a residential function, the area in which it is prohibited to locate residential buildings may be several times larger than ten times the total height of the wind turbine.

Furthermore, the distance criterion will not be the only factor determining the parties to the power plant building permit procedure. In any case of facility localization being subject to an environmental impact assessment, the constraints on that location will also be determined by results of the assessment conducted in this regard, taking into account a number of specific local conditions, the identification of which requires individual analyses for a particular facility and site. It should be emphasized that these other factors will be taken into account as an auxiliary means, with the absolute obligation to maintain the distance norm. Provisions on this issue should be included in the amendment of the Regulation of the Minister of the Environment on Permissible Noise Levels in the Environment, by specifying acceptable levels of infrasound noise in the environment, and it is also necessary to define a methodology for evaluating the noise level generated by wind farms during their optimal operation.

The introduction of such restrictive distance standards is an unprecedented, in the Polish investment law, example of limiting property rights and the principle of economic freedom; a restriction which in a democratic state governed by the rule of law can only be established subject to the principle of proportionality. This means that this limitation must be able to achieve the intended objectives, it must be necessary to protect the interest with which it is linked, and its effects must be proportionate to the burden imposed on the citizen. ${ }^{12}$

Therefore, the prohibition on the location of wind turbines at a distance of $1.5-2 \mathrm{~km}$ from residential buildings and the prohibition of locating dwellings at this distance from wind turbines (within the radius of $1.5-2 \mathrm{~km}$ from an existing power plant will result in an area excluded from housing) should be dictated by a reliably documented, proven risk posed by this type of activity to human life and health (technical disasters, frequent failures that would result in fatalities and serious material losses, diseases caused by wind turbines). So far, two wind turbine failures have occurred in Poland, resulting in disintegration of the rotor and destruction of the nacelle, and no one was injured and no one - apart from the energy provider - suffered material loss.

Such radical limitation of options for the location of wind power plants in Poland brings to mind that this type of energy generation is more dangerous to human life and health than thermal energy (coal, gas) and even nuclear energy, which is almost absurd.

12 Judgements of the Constitutional Court: of 9 June 1998, K 28/97, OTK 1998, No. 4, item 50; of 26 April 1999, K 33/98, OTK 1999, No. 4, item 71; of 2 June 1999, K 34/98, OTK 1999, No. 5, item 94; of 21 April 2004, K 33/03, OTK-A 2004, No. 4, item 31. 
The legislature's primary goal of protecting human settlements from noise and infrasound could be achieved in a far less invasive way by introducing noise emission standards for wind turbines and special criteria for evaluating such type of noise. The legislative initiative of the Minister of the Environment would be sufficient to regulate this issue by way of a regulation, while the protection against shadow flicker could be achieved by introducing a flickering limit (e.g. by means of an obligation of temporary shutdown). It was possible to use the experience of countries with a well-developed wind energy sector, including Denmark, where distance standards are much more liberal than those currently applicable in Poland (as a rule: four times the turbine height) and appropriate noise limits, infrasound limits and shadow flicker limits were adopted to ensure a proper level of human protection.

If a particular target is achievable by another measure which imposes less restrictions on rights and freedoms, then the use of a more restrictive measure by the legislature goes beyond what is necessary and, therefore, infringes the Constitution of the Republic of Poland ${ }^{13}$.

It should be also emphasized that the compliance with the distances provided for in Art. 4 u.i.e.w. is not required for the reconstruction, outward extension, upward extension, renovation, assembly or reconstruction of a residential or mixed-use building with a residential function. This law, however, is limited in the opposite way, i.e. in the case of wind turbines, where observing these distances is not required only in the case of power plant repairs and other activities necessary for the proper operation of the power plant, excluding activities leading to increased operational parameters of the power plant or increase in its environmental impacts. This means that the upward extension, outward extension and reconstruction of the power plant are permissible only when the distances referred to in Art. 4 of the Act are kept. Such a one-sided restriction of investor's rights is in contradiction to the constitutional principle of equality.

\section{CONCLUSIONS}

The possibility of locating wind farms solely on the basis of a local plan, taking into account the distance norms contained in the Act, raises legitimate doubts as to the compliance with the general principles of the rule of law expressed in the Polish Constitution. This refers mainly to the principle of equality expressed in Art. $32 \S 2$, which requires equal treatment - without both discriminatory and favouring distinction of entities of equal character, and the principle of protection of property (Art. $64 \S 1$ and 2), the principle of freedom to choose and pursue economic activity (Art. 22) and the principle of proportionality (Art. $31 \S 3$ ).

13 Judgement of the Constitutional Court of 10 April 2002, K 26/00, OTK-A No. 2/2002, item 18. 
The protection of human and civil freedoms and rights is not limited only to the establishment by the legislator of substantive and procedural institutions protecting specific property rights, but also contains the obligation to refrain from adopting regulations that may deprive of legal protection or excessively limit that protection. ${ }^{14}$

The Act undoubtedly deprives entrepreneurs who want to invest in wind energy of the possibility of obtaining a decision on development conditions in a situation when other entrepreneurs have such a possibility, i.e. those investing in conventional energy or so-called photovoltaic farms, which also face strong opposition by the public.

Although the freedom of economic activity is not an absolute freedom and is subject to restrictions, they can only be implemented in line with constitutional standards, which means, inter alia, the need to demonstrate that the introduction of a given restriction was due to an important public interest and the observance of the principle of proportionality. The provisions of the Act in question raise serious concerns in this regard. It is understood that the "public interest" consists of such values and states that contribute to the good of as many people as possible interested in a given decision or situation, and which satisfy the interests and needs of the widest possible circle of citizens, at the same time causing harm or negation of individual interest to as few people as possible..$^{15}$ At the same time, neither the interpretation of particular provisions of the Act nor the reading of the grounds for its draft, lead to the thesis that its regulations were supposed to protect the legitimate interests of a particular social group. On the contrary, the wind power plant construction sector worldwide is seen as encouraging the development of ecological, renewable energy sources that serve both consumers and investors, and, thus, have a positive impact on local business development and energy security.

The legislature's goal of simplifying and increasing the transparency of the wind farm building permit process has come at too high a cost; at the expense of violating basic constitutional standards, notably the principle of proportionality and the principle of protection of property. Moreover, the provisions of the Act are an unprecedented interference in one of the foundations of the idea of decentralization, namely the principle of local authority's powers of planning.

First of all, the norms contained in the Act will prevent landowners from applying for decisions determining the conditions of development for buildings with residential function. item 320 .

${ }_{14}$ Judgement of the Constitutional Court of 13 April 1999, K 36/98, Journal of Laws No. 34,

15 M. Safjan, L. Bosek (red.), Konstytucja RP. Tom I. Komentarz do art. 1-86, Warszawa 2015, p. 233. Judgement of the Constitutional Court of 21 December 2005, K 45/05, OTK-A 2005, No. 11, item 140; Judgement of the Constitutional Court of 8 July 2008, K 46/07, OTK-A 2008, No. 6, item 10. 
Secondly, due to the requirement that local plans providing for the location of a wind power plant be drawn up for areas where new residential buildings cannot be located, and whose boundaries are determined taking into account the maximum total height of the wind power plant, it will become impossible to adopt such plans in many small-scale municipalities. It should be borne in mind that the area covered by the local plan may not go beyond the area of jurisdiction of the municipal council that adopts this plan. On the other hand, the distance standards for wind power plants introduce a "back door" ban on carrying out economic activities in these municipalities, involving the establishment and operation of wind turbines.

Thirdly, and most importantly, there is a serious risk of infringing the principle of proportionality, as there are no sufficient arguments in favour of such a material limitation on the ownership of real estate. Such rigid distance standards, ignoring any special circumstances, do not apply to the localization of other investments that may adversely affect the environment, including mobile telephony towers.

This legal status means a significant change in the direction of the Polish energy policy and raises concerns about the country's ability to meet its commitment to achieve a 15\% share of Renewable Energy Sources in total gross energy consumption in 2020, resulting from Annex 1 to the Directive of 23 April 2009, 2009/28/EC ${ }^{16}$ on the promotion of the use of energy from renewable sources. Given the spatial structure of our country, the Act actually prohibits many municipalities to establish such power plants in their area, and for real estate owners it drastically reduces the possibility of using these properties for housing purposes.

\section{BIBLIOGRAPHY}

Act of 21 March 1991 on maritime areas of the Republic of Poland and maritime administration, Journal of Laws of 2013, item 934.

Act of 7 July 1994 - Construction Law, Journal of Laws of 2016, item 290.

Act of 21 August 1997 on Real Estate Management, Journal of Laws of 2015, item 1774.

Act of 27 March 2003 on Spatial Planning and Land Development, Journal of Laws of 2016, item 778.

Act of 20 February 2015 on Renewable Energy Sources, Journal of Laws of 2016, item 925. Act of 20 May 2016 on Investments in Wind Power Plants, Journal of Laws, item 961. Annex 1 to the Directive of 23 April 2009, 2009/28/EC, OJ EU L No. 140, item 16. Judgement of the Constitutional Court of 9 June 1998, K 28/97, OTK 1998, No. 4, item 50. Judgement of the Constitutional Court of 13 April 1999, K 36/98, Journal of Laws No. 34, item 320. Judgement of the Constitutional Court of 26 April 1999, K 33/98, OTK 1999, No. 4, item 71. Judgement of the Constitutional Court of 2 June 1999, K 34/98, OTK 1999, No. 5, item 94. Judgement of the Constitutional Court of 10 April 2002, K 26/00, OTK-A No. 2/2002, item 18. Judgement of the Constitutional Court of 21 April 2004, K 33/03, OTK-A 2004, No. 4, item 31.

${ }^{16}$ OJ EU L No. 140, item 16. 
Judgement of the Constitutional Court of 21 December 2005, K 45/05, OTK-A 2005, No. 11, item 140. Judgement of the Constitutional Court of 8 July 2008, K 46/07, OTK-A 2008, No. 6, item 10.

Judgement of the Supreme Administrative Court of 13 September 2005, II OSK 64/05, LEX No. 194989.

Judgement of the Supreme Administrative Court of 16 May 2014, II OSK 2980/12, LEX No. 1586384.

Judgement of the Regional Administrative Court in Łódź of 28 May 2007, II SA/Łd 1046/07, LEX No. 486528.

Judgement of the Regional Administrative Court of 25 September 2008, II SA/Bk 441/08, LEX No. 475214.

Judgement of the Regional Administrative Court in Białystok of 10 June 2010, II SA/Bk 288/10, LEX No. 737343.

Regulation of the Minister of Environment of 14 June 2007 on Permissible Noise Levels in the Environment, consolidated text Journal of Laws of 2014, item 112.

Safjan, M., Bosek, L. (red.), Konstytucja RP. Tom I. Komentarz do art. 1-86, Warszawa 2015.

\section{SUMMARY}

On July 15, 2016, a legal act entered into force, which electrified the business community, especially the unconventional energy industry, local government authorities, and all those who saw the development of the alternative energy sector as the only solution for the global energy crisis. This is about the Act of 20 May 2016 on Investments in Wind Power Plants, which set out the conditions, rules and procedures for the location and operation of wind farms with a power greater than the power of a micro installation, as well as the conditions for the location of housing developments (residential buildings and mixed-use buildings) in the vicinity of wind farms. This Act has been named, both by scholars of law and the media, "another special legislation", although it is not a typical special legislation. Although it is a lex specialis in relation to the Act of 7 July 1994 Construction Law, as well as the Act of 27 March 2003 on Spatial Planning and Land Development, its provisions, unlike any "special legislation", do not introduce preferential conditions for investors with regard to identifying location and authorization for the project covered by it. On the contrary, they introduce a number of significant constraints in the process. The legislature's goal of increasing the transparency of the wind farm building permit process has come at too high a cost; at the expense of violating basic constitutional standards, notably the principle of proportionality and the principle of protection of property.

Keywords: alternative energy; energy crisis; location of the wind farm; residential buildings; principle of proportionality; protection of property

\section{STRESZCZENIE}

W dniu 15 lipca 2016 r. wszedł w życie akt prawny, który zelektryzował środowisko przedsiębiorców (zwłaszcza z branży energetyki niekonwencjonalnej), władze samorządów gminnych oraz wszystkich tych, którzy w rozwoju sektora alternatywnych źródeł energii upatrują jedynego antidotum na globalny kryzys energetyczny. Mowa tu o ustawie z dnia 20 maja 2016 r. o inwestycjach w zakresie elektrowni wiatrowych, która określiła warunki, zasady i tryb lokalizacji oraz realizacji elektrowni wiatrowych o mocy większej niż moc mikroinstalacji, a także warunki lokalizacji zabudowy mieszkaniowej (budynków mieszkalnych i budynków o funkcji mieszanej, w skład których wchodzi funkcja mieszkalna) w sąsiedztwie elektrowni wiatrowych. Ustawa ta zarówno przez doktrynę prawa, jak i media została okrzyknięta mianem „kolejnej specustawy”, mimo że typową 
„specustawą” nie jest. Jej regulacje, w odróżnieniu od „specustaw”, nie wprowadzają dla inwestorów preferencyjnych warunków ustalania lokalizacji i udzielania pozwolenia na realizację objętych nią inwestycji. Cel ustawodawcy, którym było zwiększenie transparentności procesu uzyskiwania pozwolenia na realizację elektrowni wiatrowej, został jednak osiągnięty zbyt dużym kosztem - złamania podstawowych standardów konstytucyjnych, na czele z zasadą proporcjonalności i zasadą ochrony własności.

Słowa kluczowe: energia alternatywna; kryzys energetyczny; lokalizacja farmy wiatrowej; budownictwo mieszkaniowe; zasada proporcjonalności; ochrona własności 
